\title{
Predation within meiofaunal communities: description and results of a rapid-freezing method of investigation
}

\author{
Andrew D. Kennedy* \\ Department of Biological Sciences, Hatherly Laboratories, University of Exeter, Exeter EX4 4PS, United Kingdorn
}

\begin{abstract}
A technique for studying field interstitial meiofaunal predation is described. Tested on mud and sand communities in the Exe Estuary, southwest England, the methodology provided evidence for the complexity of field-based meiobenthic trophic interactions. Nematoda and Turbellaria were implicated in 2 types of predation: (1) direct carnivory, whereby one meiofaunal individual was ingested by another; (2) internal predation, whereby small nematodes invaded the bodies of other meiofauna in a manner that might have been parasitism, carnivory or scavenging. Prey items included nematodes, harpacticoid copepods, ostracods, annelids and halacarids. The freezing technique was evaluated against alternative methodologies for studying meiofaunal feeding interactions: advantages include directness (i.e. no use of an intermediate assay) and field pertinence (animals are fixed within seconds of in situ sampling). However, the technique is time-consuming and only provides a 'snapshot' of each predatory interaction, i.e. the subsequent outcome can only be assumed. Photographs are presented showing incidents of meiofaunal predation.
\end{abstract}

KEY WORDS: Meiofauna Feeding interactions Experimental technique - Nematoda - Turbellaria

\section{INTRODUCTION}

Although the importance of meiofauna to marine trophic dynamics is now widely acknowledged (Gerlach 1971, Fenchel 1978, Kuipers et al. 1981), their exact position in the benthic foodweb remains a subject of considerable controversy. The organisms' high abundance, ubiquitous distribution, rapid generation time and fast metabolic rate suggest a significant role in energy transfer. However, a crucial and still-open question is the extent to which this transfer occurs up the size spectrum, ultimately to commercially important food species for man, or alternatively to other meiofaunal-size organisms, yielding a self-contained meiobenthic energy sink.

Considerable research has sought to elucidate meiofaunal trophic relationships. Unfortunately, progress in this field has been hindered by the organisms' minia-

- Present address: Division of Fisheries, CSIRO Marine Laboratories, PO Box 20, North Beach, WA 6020, Australia ture size, fragile structure and positive geotaxis, which together make direct field observation of predatorprey encounters difficult. The comparative ease with which macrofauna can be manipulated means that, while substantial evidence for a macrofauna-meiofauna trophic link now exists (see reviews by Gee 1989, Coull 1990), only limited information on feeding interactions within the meiofaunal community is available (see Romeyn \& Bouwman 1983, Watzin 1985, Jensen 1987). Meiofauna are believed to be highly selective feeders with distinct and often highly specialized food niches, reflecting their diverse buccal adaptations (Feller \& Warwick 1988). However, information on the exact identity of their food sources, and hence the extent to which internal predation occurs, remains scarce.

Uncertainty over meiofaunal feeding relationships may in part be attributed to methodological uncertainties: to date, most experiments investigating meiofaunal consumption have adopted an indirect approach. Laboratory feeding trials assess the effects of potential food materials on population growth, distribution, reproduc- 
tion, or physiological efficiencies (e.g. Gray 1968, Vandenberghe \& Bergmans 1981, Rieper 1982, Ustach 1982), or alternatively measure the performance of the consumer species at different levels of the same food (e.g. Schiemer et al, 1980). Techniques assessing field food sources include radioisotope tracers (e.g. ${ }^{14} \mathrm{C},{ }^{32} \mathrm{P}$, and ${ }^{3} \mathrm{H}$ glucose), whereby the transfer of a label between different organisms is monitored (e.g. Nicholas \& Viswanathan 1975, Lopez et al. 1979, Findlay \& Tenore 1982, Montagna 1984, Montagna \& Bauer 1988), and serology, through which food-specific antigens are identified (e.g. Boreham \& Ohiagu 1978, Feller et al. 1979, Feller 1984). While much valuable information may be contributed by such studies, their indirect nature raises questions of field relevance and experimental artifact (Conover \& Francis 1973, Watzin 1985, Bell 1988). There is little doubt that conclusive evidence for meiofaunal predation may best be derived from direct examination of in situ field communities.

In this paper, a technique for studying field meiofaunal predation is described that minimizes opportunities for the introduction of experimental artifact. Application of liquid nitrogen to sediment cores kills meiofauna so rapidly that a proportion are preserved in the act of predation. Density separation of organic from inorganic material, followed by photomicroscopy, then allow these feeding interactions to be recorded. If the liquid nitrogen is transported into the field and fixation is performed immediately post-sampling, disturbance effects are minimized and the in situ authenticity of feeding interactions is virtually guaranteed. The technique thus provides a method for validating the results of indirect research.

\section{METHODS}

Study site. The investigation was carried out on the Exe Estuary, southwest England (50 $38^{\prime} \mathrm{N}, 3^{\circ} 26^{\prime} \mathrm{W}$ ). A detailed description of the physical and chemical nature of the estuary has been given by Boalch (1980). Earlier work on its meiofaunal trophic structure has been described by Warwick (1982), Gee (1987) and Kennedy $(1993,1994)$.

Two sites were selected for meiofauna sampling, a sand flat near Exmouth (50 40 $20^{\prime \prime} \mathrm{N}, 3^{\circ} 26^{\prime} 25^{\prime \prime} \mathrm{W}$ ) and a mud flat at Exton $\left(50^{\circ} 37^{\prime} 45^{\prime \prime} \mathrm{N}, 3^{\circ} 25^{\prime} 30^{\prime \prime} \mathrm{W}\right)$. The former site was composed of fine, tightly packed sand with a shallow $\mathrm{H}_{2} \mathrm{~S}$ layer, while at the latter site the mud was loose and liquid, retaining a considerable quantity of water at low tide. These substrata are representative of the range of benthic habitats found on the estuary (Wells 1961).

Meiofauna sampling. Twelve sediment cores were taken at each site using a stratified random sampling design, each sample separated by a distance of $10 \mathrm{~m}$. The samples were collected using surgical syringes which had been modified for the purpose by the removal of one end. To reflect the greater abundance of meiofauna in mud than in sand, syringes $50 \mathrm{~mm}$ long and $16 \mathrm{~mm}$ in diameter were used for sampling the mud substratum while syringes $100 \mathrm{~mm}$ long and $26 \mathrm{~mm}$ in diameter were used for the sand. These dimensions conform to the recommendations of McIntyre \& Warwick (1984) and yield sample volumes of 10.1 and $53.1 \mathrm{~cm}^{3}$ respectively.

Fixation and analysis. Immediately after sampling, the sediment cores were extruded from the syringes and dropped gently into steel vacuum flasks (internal capacity $1 \mathrm{l}$ ) that had been prefilled with liquid nitrogen (to the $600 \mathrm{ml}$ level). Three sediment cores were placed in each flask. After the initial displacement and emission of gases had subsided, corks were used to lightly cover the cylinders, but without sealing them to prevent build-up of pressure.

In the laboratory, the sediment samples were thawed gradually by removing the corks from the flasks and allowing the liquid nitrogen to evaporate. After thawing was complete, fixation was achieved by adding a $4 \%$ formalin solution prepared using $45 \mu \mathrm{m}$ filtered sea water. Meiofauna were extracted from the samples using a modification (Austen 1986) of the 'Ludox-TM' (Du Pont, Ltd, Stevenage, UK) density separation technique (de Jonge \& Bouwman 1977).

The extracted meiofauna were transferred to anhydrous glycerine by the slow evaporation method of Seinhorst (1959). Low concentrations of the organisms in suspension were then mounted on glass microscope slides. Cover slips were placed carefully over the preparations and air pockets filled using 'Clearseal' (Northern Biological Supplies, Ipswich, UK). Slides were sealed using the gas-impervious 'Bioseal I' (Northern Biological Supplies) to create semipermanent mounts. The slides were scanned at low power under a compound microscope to locate incidents of meiofaunal predation. When predatory encounters were discovered, high power was used to identify the species involved to the highest taxonomic level possible. Photographic records of the encounters were also taken.

\section{RESULTS}

\section{Experimental technique}

Instantaneous freezing using liquid nitrogen successfully preserved meiofauna in the act of predation. A variety of incidents involving the partial digestion of a prey organism by predatory meiofauna was observed; examples of these interactions are shown in Figs. 1 to 8. 


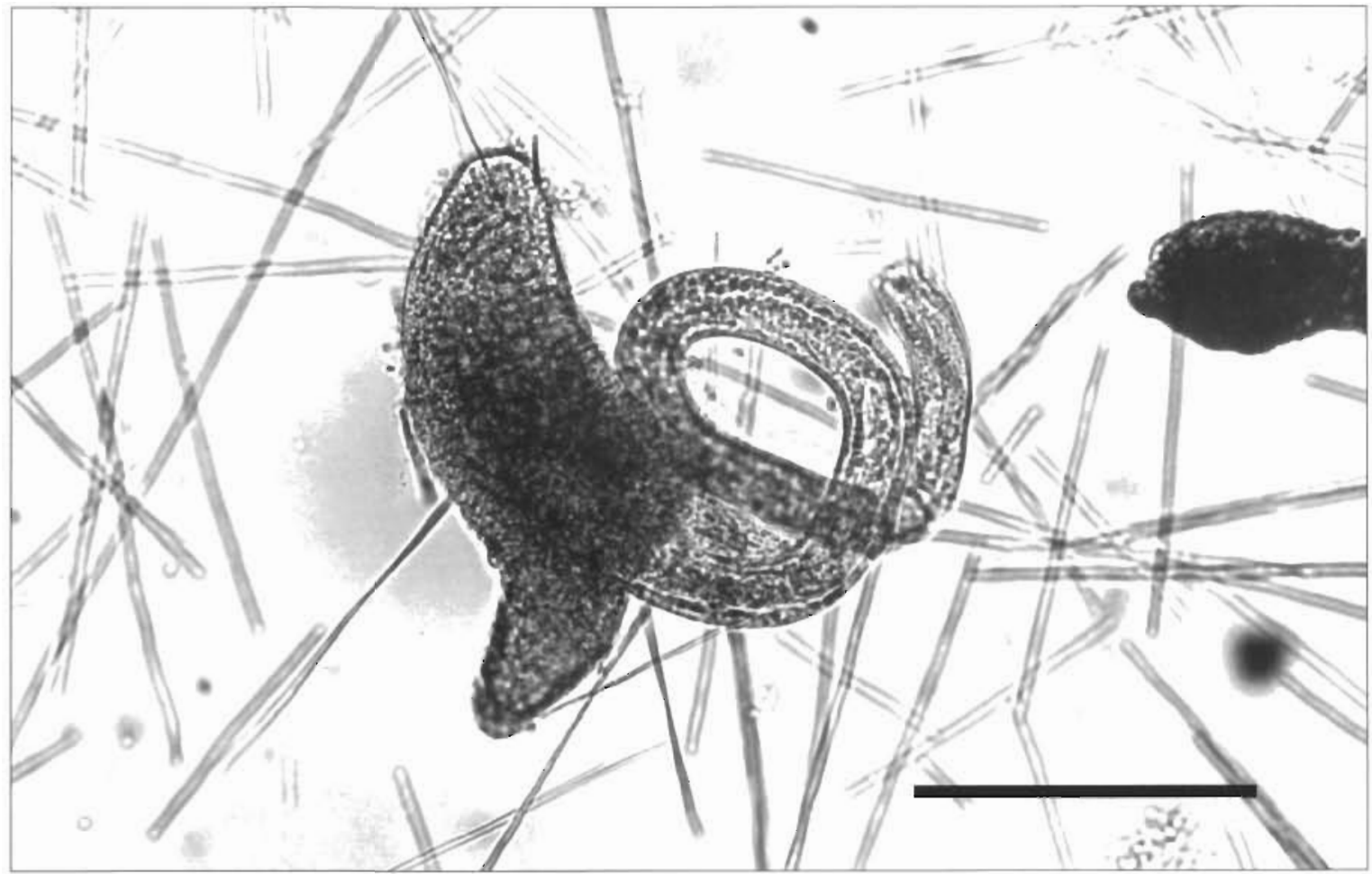

Fig. 1. Paralostomum spp. (Turbellaria, Macrostomidae) ingesting nematode tail-first (scale bar $=200 \mu \mathrm{m}$ )

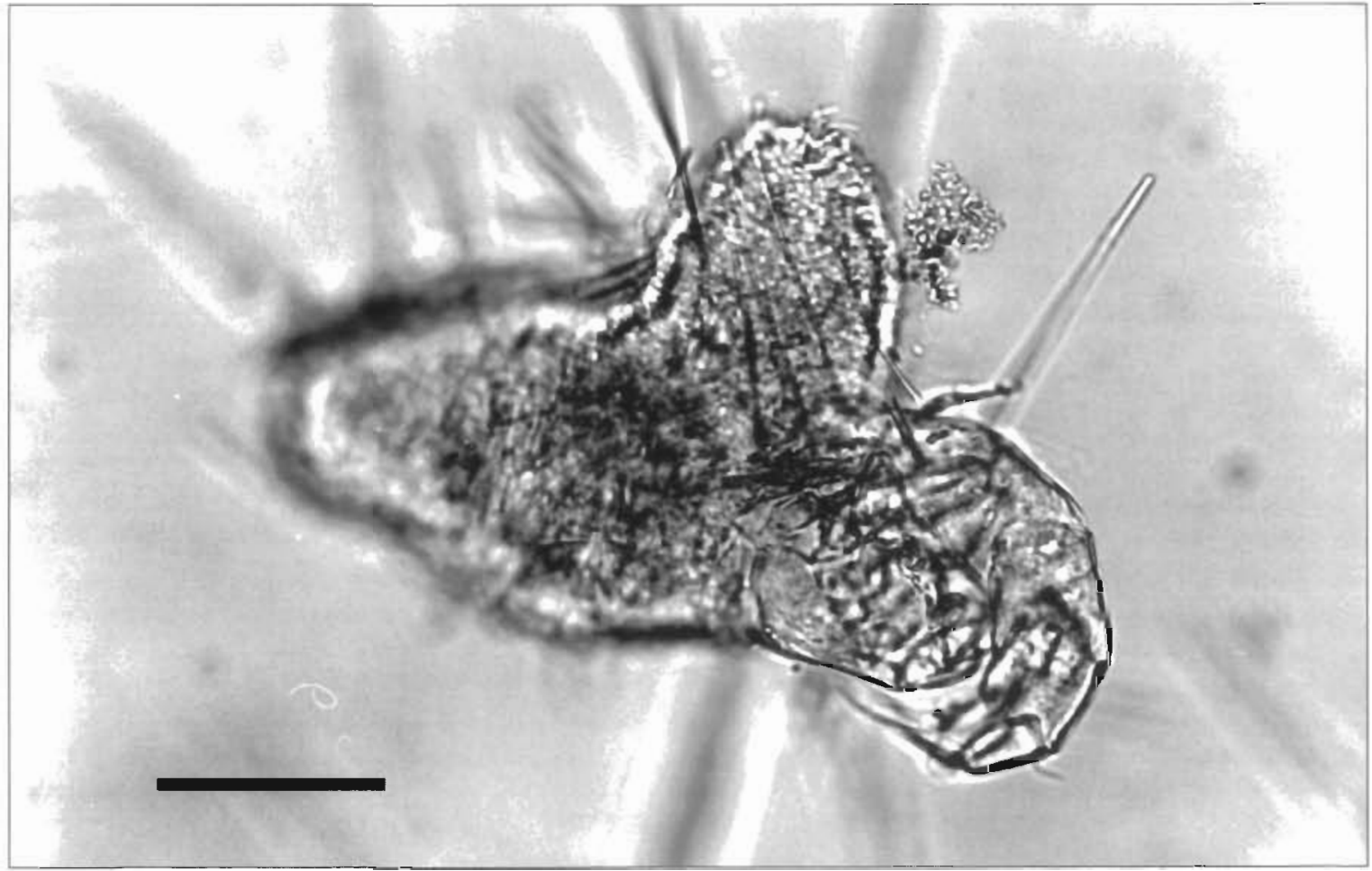

Fig. 2. Unidentified turbellarian ingesting harpacticoid copepod tail-first (scale bar $=100 \mu \mathrm{m}$ ) 


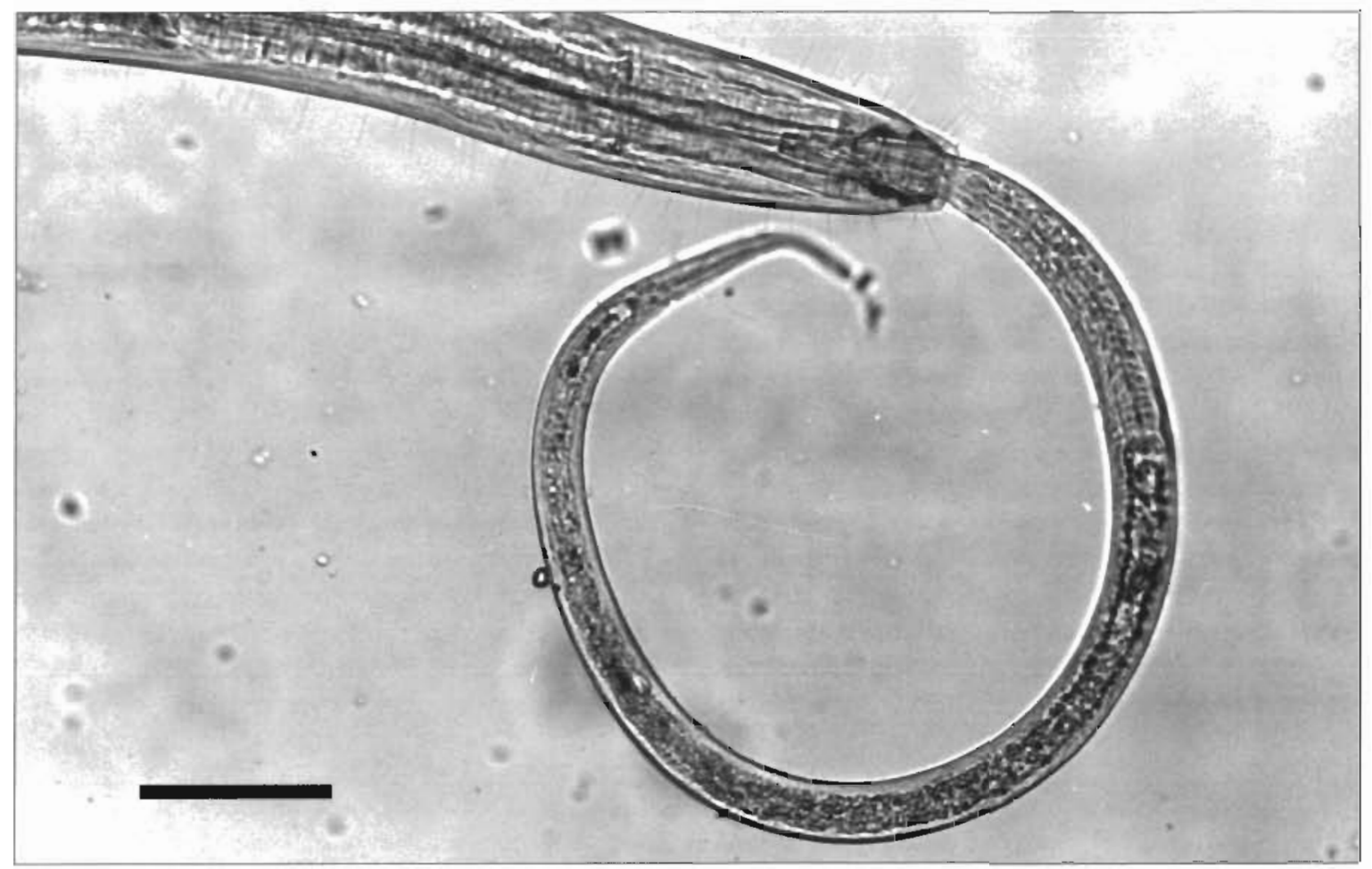

Fig. 3. Sphaerolaimus hirsutus ingesting an Oncholaimellus calvadosicus head-first (scale bar $=100 \mu \mathrm{m}$ )

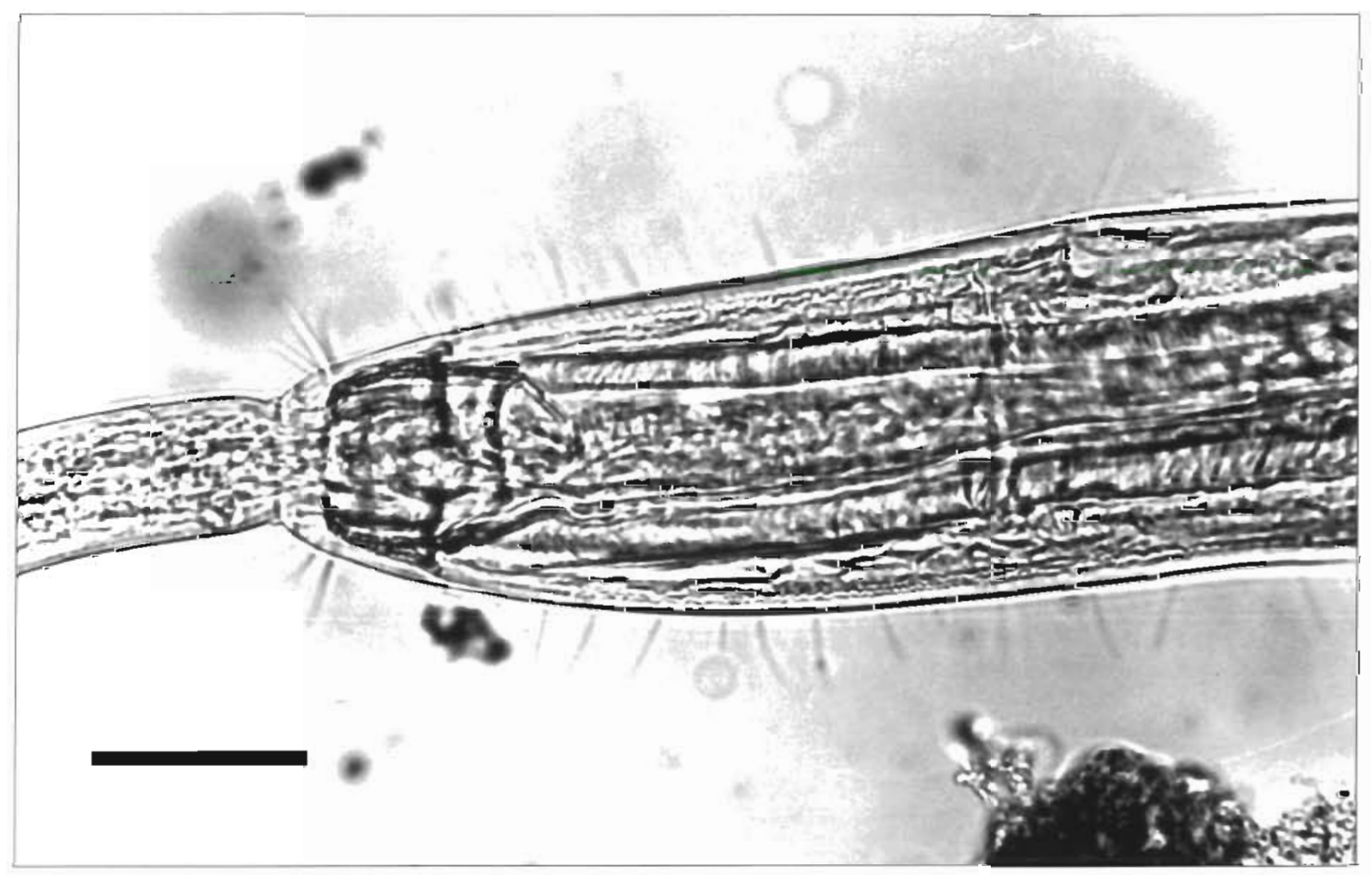

Fig. 4. High. magnification view of Sphaerolaimus hirsutus ingesting a smaller nematode tail-first (scale bar $=25 \mu \mathrm{m}$ ) 


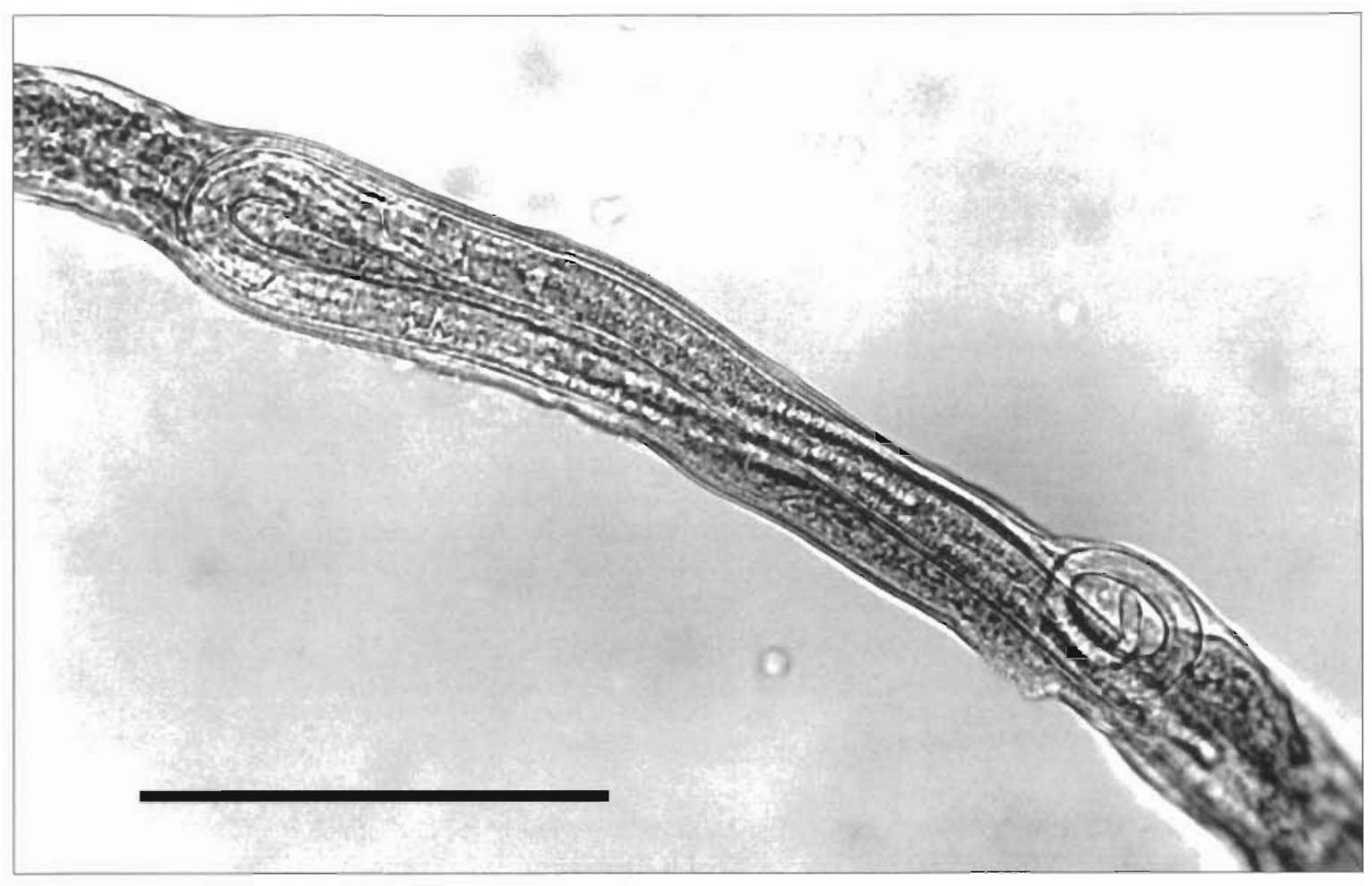

Fig. 5. Monhystera spp. inside remains of Gammanema conicauda (scale bar $=200 \mu \mathrm{m}$ )

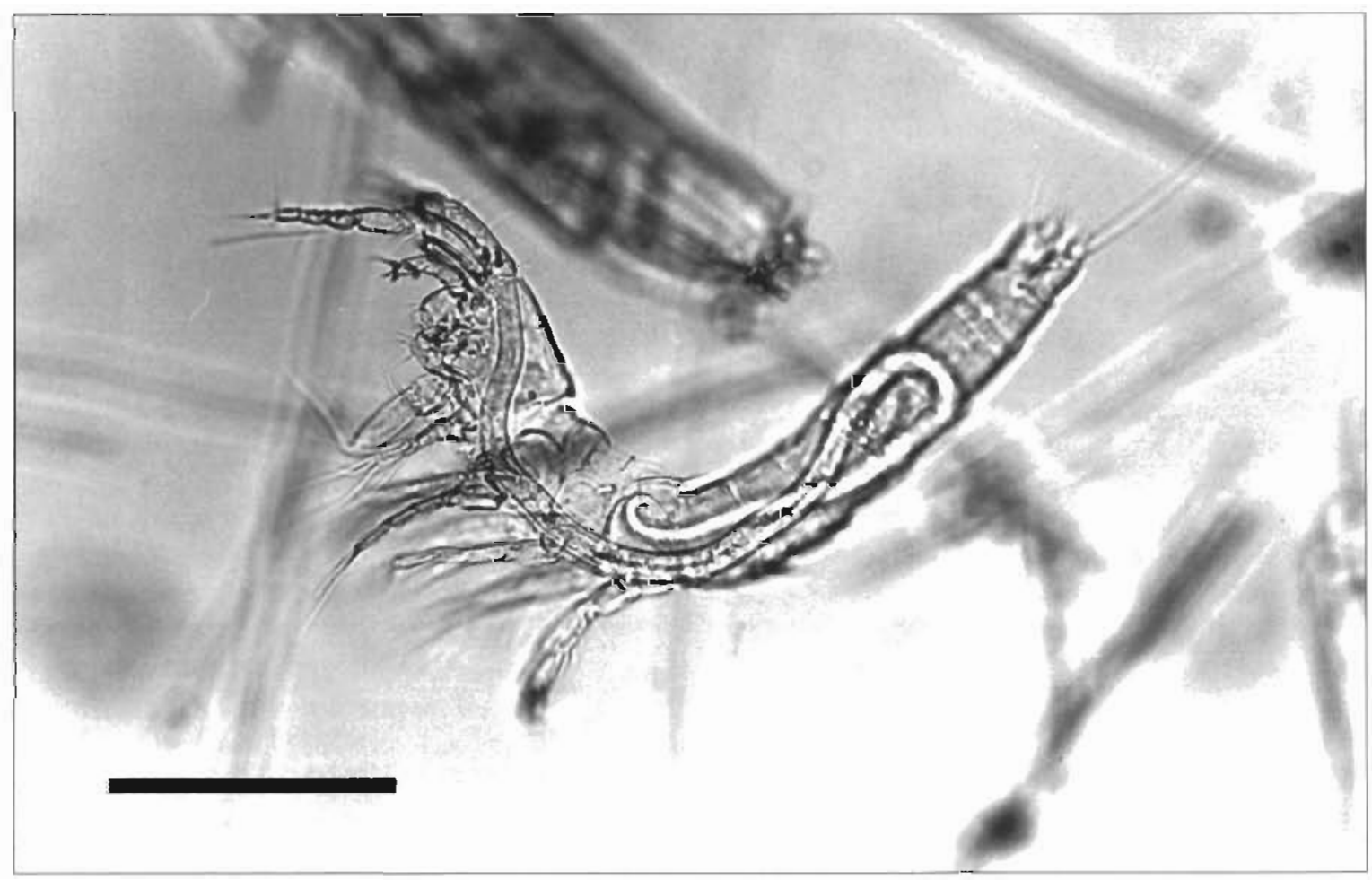

Fig. 6. Monhystera spp. inside Paraleptastacus spp. $($ scale bar $=200 \mu \mathrm{m})$ 


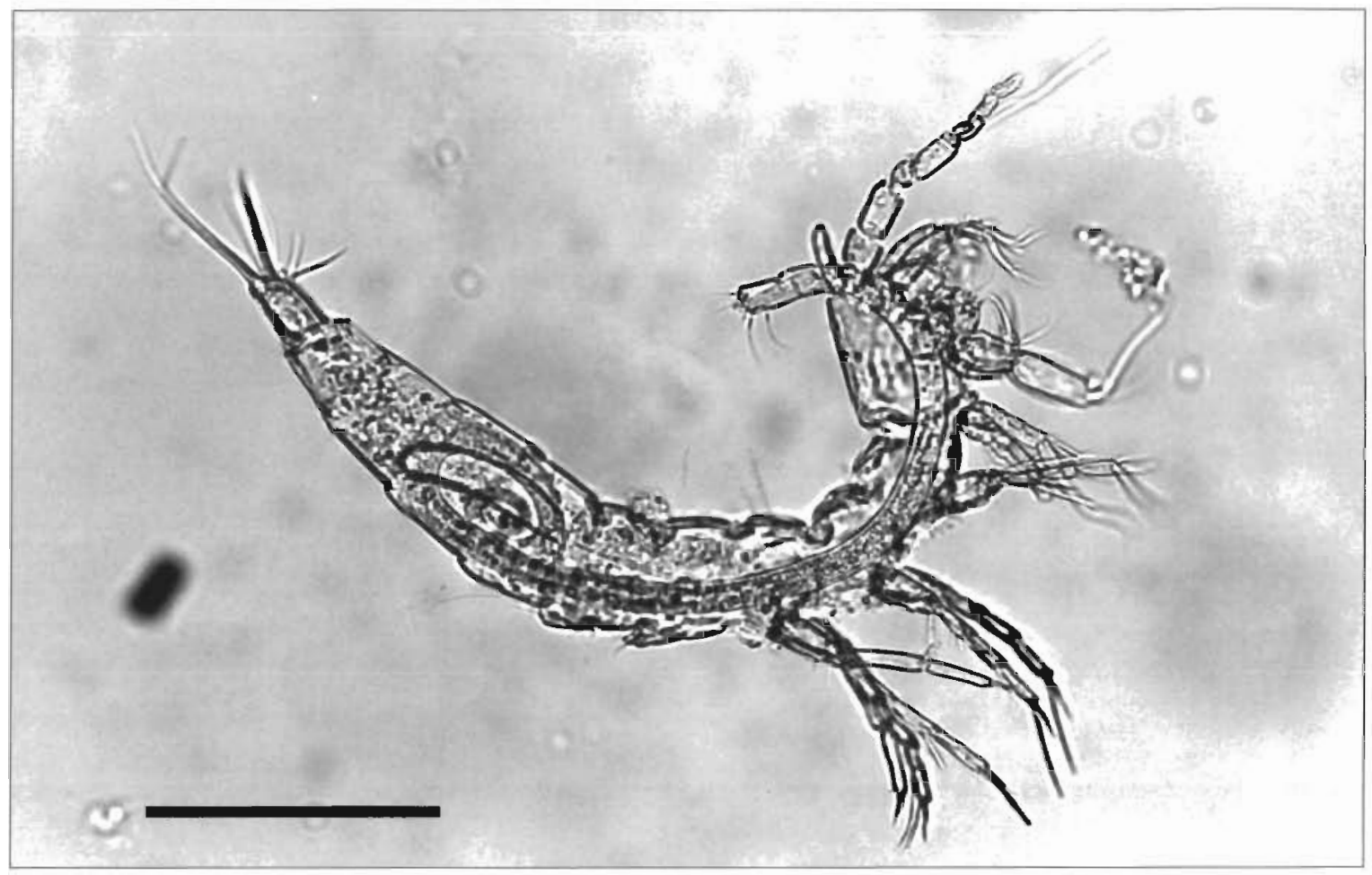

Fig. 7. Monhystera spp. inside Arenocaris bifida (scale bar $=200 \mu \mathrm{m}$ )

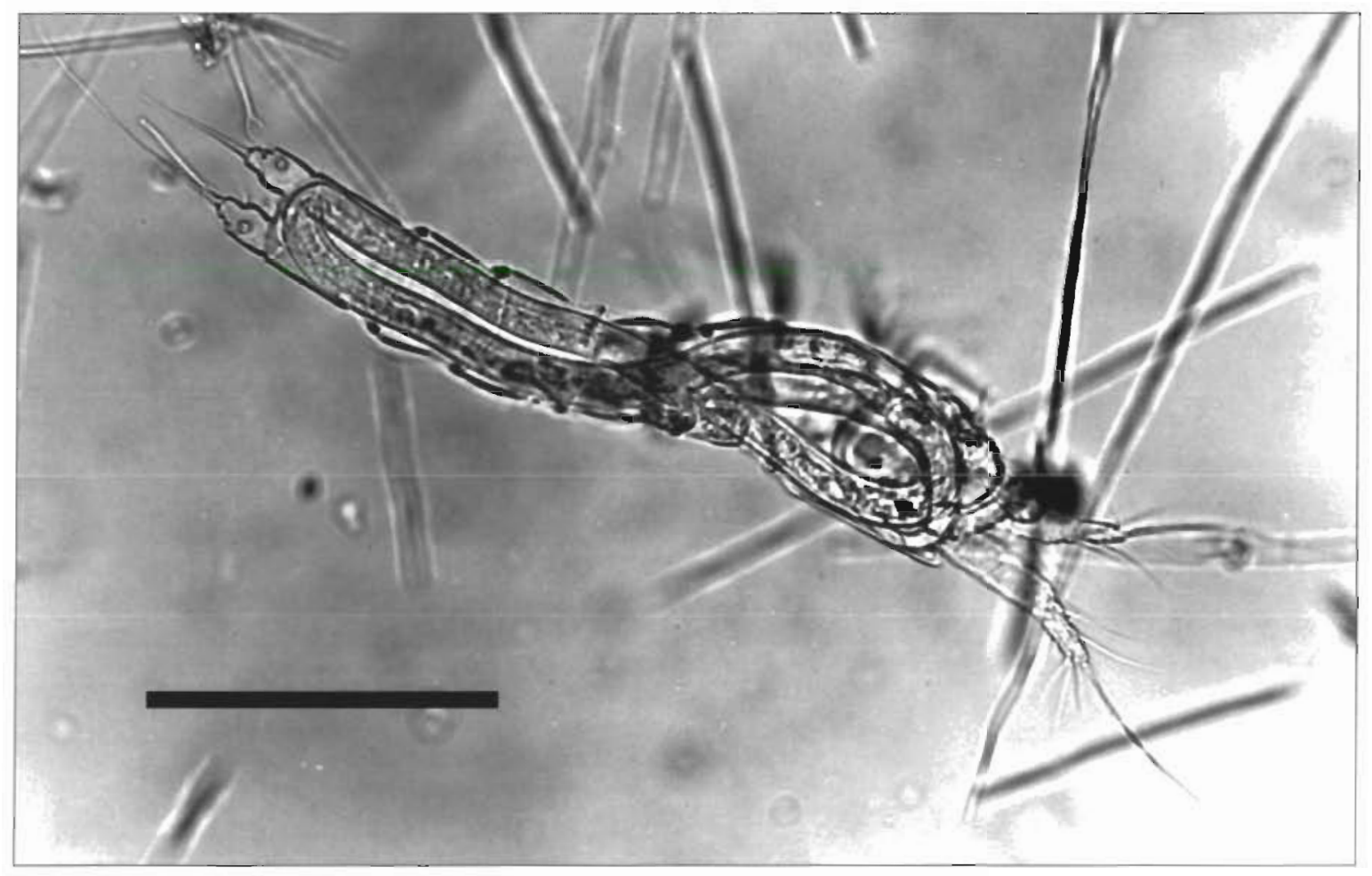

Fig. 8. Monhystera spp. inside mostly digested harpacticoid copepod (scale bar $=200 \mu \mathrm{m}$ ) 
Apart from the logistical difficulties of transporting liquid nitrogen into the field, no serious disadvantages were associated with the technique. Providing gloves were worn, and care taken not to touch the fluid, placing sediment cores in liquid nitrogen entailed no risk of personal injury (the wearing of safety goggles is, however, recommended). On contact with the liquid nitrogen, the cores retained their cylindrical structure, and no splintering or shattering occurred. After returning the samples to the laboratory, the meiofauna preserved well in $4 \%$ formalin solution, and no structural damage or artifacts caused by freezing were visible.

In common with many techniques for investigating meiofaunal ecology, the liquid nitrogen method was time-consuming. Density-separation of organisms from the sediment is a slow process, and the finished slides then have to be scanned to locate incidents of meiofaunal predation. A less labour-intensive postfreezing extraction technique such as elutriation (Boisseau 1957) would reduce the time needed to separate meiofauna from the sediment, but slide mounting and scanning would still be required. In the present study, recorded incidents of feeding interactions were further limited by the ratio of predatory encounters to total meiofauna present being extremely low.

A second limitation of the technique was the difficulty encountered in successfully identifying meiofauna to species level. Ingestion by predatory taxa often caused important anatomical features such as amphids, pharyngeal organs, pigment spots and cephalic setae to be obscured. Accurate identification of soft-bodied meiofauna such as turbellarians is often only possible using live material, so for these taxa the usefulness of liquid nitrogen is limited.

\section{Feeding interactions}

During this study, 2 types of predatory interactions were recorded. First, there were incidents of direct carnivory, whereby one meiofaunal individual was ingested by another (e.g. Figs. 1 to 4). Second, there were incidents where small nematodes were observed inside the bodies of other meiofauna, in a manner that might have been parasitism, carnivory or scavenging (e.g. Figs. 5 to 8). Since both categories of feeding involve energy flow from one species to another species, they may equally be considered types of 'predation' (Pimm 1982).

Predators that fell into the first category were nematodes and turbellarians. Members of both groups were photographed in the act of ingesting other meiofauna. However, the range of prey items was limited. Turbellarians fed only upon nematodes and harpacticoid copepods, while nematodes only ingested other mem- bers of their own phylum. In many cases the prey appeared too large to be feasibly swallowed, suggesting that mastication or breaking-up of the prey item would be an essential prerequisite to successful ingestion. In general, prey were ingested from the tailend first.

Incidents where nematodes were observed inside the bodies of other meiofauna were particularly common at the sand site. A range of prey taxa was recorded, including harpacticoid copepods, annelids, ostracods, halacarids and other nematodes. In some cases all that remained of the prey item was the indigestible carapace or cuticle, suggesting that the nematode might have been acting as a scavenger or, alternatively, feeding on bacteria dwelling inside the exoskeleton. However, in other cases the prey item was still intact, suggesting that either invasion of its body by the predator was the cause of death or, alternatively, that at the time of freezing the prey organism may still have been alive.

\section{DISCUSSION}

\section{Experimental technique}

Freezing of sediment samples using liquid nitrogen appears to provide a valuable technique for studying in situ meiofaunal predation. Because only field-fresh samples are used, and predatory encounters are recorded directly (i.e. without resort to intermediate assays), the technique minimises the possibility of producing results biased by experimental artifact or field irrelevance: predation incidents visible beneath the microscope suggest true predation within the benthos. However, as individual encounters only are recorded, a large number of incidents are required before the generality of such predation can be guaranteed.

A shortcoming associated with the technique is that it only provides an instantaneous picture, or 'snapshot', of those faunal interactions occurring at the time that the liquid nitrogen was applied. Thus, while partial ingestion of prey items may be seen clearly, the subsequent outcome of each encounter, for example whether the prey was successfully swallowed or instead regurgitated, can only be speculated. Care is needed in the interpretation of such results. For example, the ingestion of Oncholaimellus calvadosicus by Sphaerolaimus hirsutus, depicted in Fig. 3, could alternatively be interpreted as invasion of $S$. hirsutus by $O$. calvadosicus. Similarly, that true predation is occurring, and not just that 2 organisms are lying on top of each other on the slide, needs to be carefully confirmed. 
During this study, it was not possible to evaluate how efficiently the freezing process performed; it is not known how many predation incidents were ongoing at the time of sampling. As such, liquid nitrogen provides only qualitative, not quantitative, information on meiofaunal feeding habits. However, that predatory interactions were recorded during this study where, using standard chemical fixation techniques, they generally are not, justifies the technique's contribution to feeding studies. It may be postulated that using standard fixation techniques, for example the addition of $10 \%$ formalin solution, death occurs sufficiently slowly to allow predators to abandon or regurgitate their prey. Predatory nematodes inside the bodies of other meiofauna may, on sensing the chemical stimuli of formalin or alcohol, leave their victims before themselves being preserved. Liquid-nitrogen-induced freezing allows no opportunity for such action. The rapid rate of cooling, combined with the inhibitory effect of low temperatures on poikilotherm locomotory activity, prevents escape (the precise rate of cooling of sediment was not measured, as it would depend heavily upon the water content, i.e. thermal conductivity, of the matrix, and thus would vary widely between sites). However, since the rate of freezing is inversely proportional to the cross section of the sediment sample, only small-diameter coring devices should be used.

\section{Support for field relevance of laboratory experiments}

The results of this study support laboratory observations of turbellarian and nematode feeding behaviour. Figs. 1 \& 2, depicting Turbellaria ingesting surprisingly large prey items, match Watzin's (1985) laboratory observation of the turbellarian Neochildia fusca attacking organisms of greater size than itself. Watzin also records the 'partial predation' of vermiform prey, whereby the bodies of organisms are broken at the point where they become too large to swallow, and a 'sucking-out' predation method, in which the turbellarian's pharynx is quickly everted and thrust into its victim and the internal organs and fluids then sucked out. In the present study, the predator-prey encounter illustrated in Fig. 1 might have involved the 'partial predation' method while the encounter illustrated in Fig. 2 might have involved 'sucking out'.

Figs. 4 \& 5, illustrating Sphaerolaimus hirsutus ingesting smaller nematodes, support evidence from earlier studies of internal predation within nematode communities. Heip et al. (1978) successfully fed the $2 B$ nematode Oncholaimus oxyuris on the smaller species Panagrellus redivivus, while Chitwood \& Timm (1954) report predation on other nematodes by members of the genus Halichoanolaimus. Figs. 6 to 8, depicting small nematodes inside the bodies of other meiofauna, parallel Vranken's observations (quoted in Heip et al. 1985) of nematodes piercing the body wall of oligochaetes and moving into the victim's body to feed. Considered together, these results suggest that the liquid nitrogen technique may provide a valuable means of establishing the field relevance of laboratoryderived results.

In contrast to this conclusion, no evidence was found of meiofaunal predation by taxa other than Turbellaria and Nematoda, nor of macrofaunal predation upon meiofauna. Coelenterates, harpacticoids, halacarids, nemertines, and tardigrades have all been described as occasional predators (Garstang 1900, Viets 1927 , Newell 1947, Pennak 1951, Muus 1966, Marcotte 1977), yet samples examined here provide no support for this assertion. Possibly the liquid nitrogen technique does not lend itself to rapid fixation of such taxa, with evidence of predation being destroyed during freezing. Alternatively, in the Exe Estuary substrata tested during this experiment, these phyla may not play a significant predatory role.

Acknowledgements. This research was supported by Grant No. GT4/87/ALS/53 from the UK Natural Environment Research Council (NERC). Facilities for the study were provided by Exeter University and the NERC Plymouth Marine Laboratory. I am grateful to Drs J, M. Gee, K. Reise, E. R. Schockaext and R. M. Warwick for advice on meiofaunal taxonomy. Dr T. Harris provided field work and technical assistance.

\section{LITERATURE CITED}

Austen, M. C. (1986). Factors affecting meiobenthic community structure in the Tamar estuary. Ph.D. dissertation, Exeter University

Bell, S. S. (1988). Experimental techniques. In: Higgins, R. P., Thiel, $\mathrm{H}$. (eds.) Introduction to the study of meiofauna. Smithsonian Institute Press, Washington, DC, p. 169-180

Boalch, G. T (1980). Essays on the Exe Estuary. Special Vol. No. 2. The Devonshire Association for the Advancement of Science, Literature and Art, Exeter

Boisseau, J.-P. (1957). Technique pour l'étude quantitative de la faune interstitielle des sables. C.r. Congr. natl Soc. Savantes, Sect. Sci $1957 \cdot 117-119$

Boreham, P. F. L., Ohiagu, C. E. (1978). The use of serology in evaluating invertebrate prey-predator relationships: a review. Bull. entomol. Res. 68: 171-194

Chitwood, B. G., Timm, R. W. (1954). Free-living nematodes of the Gulf of Mexico. Gulf of Mexico, its origins, waters and marine life. Fish. Bull. Fish. Wildl. Serv. U.S. 55: $313-323$

Conover, R. J., Francis, V. (1973). The use of radioactive isotopes to measure the transfer of materials in aquatıc food chains Mar. Biol. 18: 272-283

Coull, B. C. (1990). Are members of the meiofauna food for higher trophic levels? Trans. Am. Microsc. Soc 109: $233-24.6$

de Jonge, V N., Bouwman, L. A. (1977). A simple density 
separation technique for quantitative isolation of meiobenthos using the colloidal silica Ludox-TM. Mar. Biol. 42: $143-148$

Feller, R. J. (1984). Serological tracerss of meiofaunal food. webs. Hydrobiologia 118: 119-125

Feller, R. J., Taghon, G. L., Gallagher, E. D., Kenny, G. E., Jumars, P. A. (1979). Immunological methods for food web analysis in a soft-bottom benthic community. Mar Biol. 54:61-74

Feller, R. J., Warwick, R. M. (1988). Energetics. In: Higgins, R. P., Thiel, H. (eds.) Introduction to the study of meiofauna. Smithsonian Institute Press, Washington, DC, p. $181-196$

Fenchel. T (1978). The ecology of micro- and meiobenthos. A. Rev. Ecol. Syst. 9: 99-121

Findlay, S., Tenore, K. (1982). Nitrogen source for a detrivore: detritus substrate versus associated microbes. Science 218: $371-373$

Garstang, W. (1900). Preliminary experiments on the rearing of sea-fish larvae. J. mar. biol. Ass. U.K. 6: 70-93

Gee, J. M. (1987). Impact of epibenthic predation on estuarine intertidal harpacticoid copepod populations. Mar. Biol. 96: $497-510$

Gee, J. M. (1989). An ecological and economic review of meiofauna as food for fish. Zool. J. Linn. Soc. 96: 243-261

Gerlach, S. A. (1971). On the importance of marine meiofauna for benthos communities. Oecologia 6: 179-190

Gray, J. S. (1968). An experimental approach to the ecology of the harpacticoid Leptastacus constrictus Lang. J. exp. mar. Biol. Ecol 2: 278-292

Heip, C., Smol, N., Absillis, V. (1978). Influence of temperature on the reproductive potential of Oncholaimus oxyuris (Nematoda: Oncholaimidae). Mar. Biol. 45: 255-260

Heip, C., Vincx, M., Vranken, G. (1985). The ecology of marine nematodes. Oceanogr. mar. Biol. A. Rev. 23: $399-489$

Jensen, P. (1987). Feeding ecology of free-living aquatic nematodes. Mar. Ecol. Prog. Ser. 35: 187-196

Kennedy, A. D. (1993). Minimal predation upon meiofauna by endobenthic macrofauna in the Exe Estuary, south west England. Mar. Biol. 117: 311-319

Kennedy, A. D. (1994). Carbon partitioning within meiobenthic nematode communities in the Exe Estuary, U.K. Mar. Ecol. Prog. Ser. 105: 71-78

Kuipers, B. R., de Wilde, P. A. W. J., Creutzberg, F. (1981). Energy flow in a tidal flat ecosystem. Mar. Ecol. Prog. Ser. 5: $215-221$

Lopez, G., Riemann, F., Schrage, M. (1979). Feeding biology of the brackish-water oncholaimid nematode Adoncholaimus thalassophygas. Mar. Biol. 54: 311-318

Marcotte, B. M. (1977). An introduction to the architecture and kinematics of harpacticoid (Copepoda) feeding: Tisbe furcata (Baird, 1837). Mikrofauna Meeresbod. 61. 183-196

McIntyre, A. D., Warwick, R. M. (1984). Meiofaunal tech- niques. In: Holme, N. A., McIntyre, A. D. (eds.) Methods for the study of the marine benthos, 2nd edn. IBP Handbook, No. 16. Blackwell Scientific Publications, Oxford, p. $217-244$

Montagna, P. A. (1984). In situ meaurement of meiobenthic grazing rates on sediment bactera and edaphic diatoms. Mar. Ecol. Prog. Ser. 18: 119-130

Montagna, P. A., Bauer, J. E. (1988). Partitioning radiolabelled thymidine uptake by bacteria and meiofauna using metabolic blocks and poisons in benthic feeding studies. Mar. Biol. 98: 101-110

Muus, K. (1966). Notes on the biology of Protohydra leuckarti Greef (Hydroidea, Protohydridae). Ophelia 3: 141-150

Newell, I. M. (1947). A systematic and ecological study of the Halacaridae of eastern North America. Bull. Bingham Oceanogr. Coll. 10:1-232

Nicholas, W. L., Viswanathan, S. (1975). A study of the nutrition of Caenorhabditis briggsae (Rhabditidae) fed on 14-C and 32-P labelled bacteria. Nematologica 21: 385-400

Pennak, R. W. (1951). Comparative ecology of the interstitial fauna of marine and freshwater beaches. Année biol. Sér. $327: 449-480$

Pimm, S. L. (1982). Food webs. Chapman \& Hall, Ltd, New York

Rieper, M. (1982). Feeding preferences of marine harpacticoid copepods for various species of bacteria. Mar. Ecol. Prog. Ser. 7: 303-307

Romeyn, K., Bouwman, L. A. (1983), Food selection and consumption by estuarine nematodes. Hydrobiol. Bull. 17 . $103-109$

Schiemer, F., Duncan, A., Klelowski, R. Z. (1980). A. bioenergetic study of a benthic nematode, Plectus palustris de Man 1880, throughout its life cycle. Oecologia 44: $205-212$

Seinhorst, J. W. (1959). A rapid method for the transfer of nematodes from fixative to anhydrous glycerine. Nematologica 4:67-69

Ustach, J. F. (1982). Algae, bacteria and detritus as food for the harpacticoid copepod, Heteropsyllus pseudonumn Coull and Palmer. J. exp. mar. Biol. Ecol. 64: 203-214

Vandenberghe, W., Bergmans, M. (1981). Differential food preferences in three cooccurring species of Tisbe (Copepoda: Harpacticoida). Mar. Ecol. Prog. Ser. 4: 215-219

Viets, K. (1927). Halacaridae. In: Grimple, G., Wagler, E. (eds.) Die Tierwelt der Nord- und Ostsee, Vol. XIc. Akademische Verlagsgesellschaft, Leipzig, p. 1-72

Warwick, R. M. (1982). The partitioning of secondary production among species in benthic communities. Neth. J. Sea Res. 16: $1-16$

Watzin, M. C. (1985). Interactions among temporary and permanent meiofauna: observations on the feeding and behaviour of selected taxa. Biol. Bull. 169: 397-416

Wells, J. B. J. (1961). The ecological distribution of the microfauna of the Exe Estuary with especial reference to the Copepoda. Ph.D. dissertation, Exeter University

Manuscript first received: November 26, 1993

Revised version accepted: August 25, 1994 